\title{
BERTRAND MARCHAL, La Religion de Mallarmé
}

\section{Ida Merello}

\section{OpenEdition \\ Journals}

\section{Edizione digitale}

URL: http://journals.openedition.org/studifrancesi/16635

DOI: 10.4000/studifrancesi. 16635

ISSN: 2421-5856

\section{Editore}

Rosenberg \& Sellier

\section{Edizione cartacea}

Data di pubblicazione: 1 juillet 2019

Paginazione: 182

ISSN: 0039-2944

\section{Notizia bibliografica digitale}

Ida Merello, «Bertrand marchal, La Religion de Mallarmé», Studi Francesi [Online], 187 (LXIII | I) | 2019, online dal 01 juillet 2019, consultato il 25 janvier 2021. URL: http://journals.openedition.org/ studifrancesi/16635 ; DOI: https://doi.org/10.4000/studifrancesi.16635

Questo documento è stato generato automaticamente il 25 janvier 2021.

\section{(c) (†)}

Studi Francesi è distribuita con Licenza Creative Commons Attribuzione - Non commerciale - Non opere derivate 4.0 Internazionale. 


\title{
BERTRAND MARCHAL, La Religion de Mallarmé
}

\author{
Ida Merello
}

\section{NOTIZIA}

BERTRAND MARCHAL, La Religion de Mallarmé, Paris, Droz, 2018, 732 pp.

1 Si tratta della riedizione dell'opera uscita nel 1988 e ormai introvabile, non modificata se non per i rimandi all'edizione Pléiade più recente delle Euvres complètes e della Gallimard Folio del 1995 per la Correspondance, riproposta nuovamente data l'importanza centrale negli studi mallarmeani.

2 A distanza di trent'anni dunque, si può constatare quanto il lavoro di Marchal abbia influenzato la critica successiva, che vi si è riferita come a una pietra miliare dell'interpretazione. L'A. traccia la storia della religiosità e della religione nell'Ottocento, mostrando come per Mallarmé sia stata importante l'amicizia con Léfébure, che, su suggestione hegeliana, faceva coincidere Dio con uno Spirito immanente in continuo divenire. Altrettanto importante per la visione spirituale del Nostro il lavoro "alimentare" su Les Dieux antiques: gli studi di Cox e Müller, che vedevano nelle figure degli dei la rappresentazione di forze terrestri e cosmiche contrapposte, lo avvicinano alla concezione di un inconscio universale, permeato dal senso del divino. Mallarmé non contrappone al moribondo cattolicesimo una religione del passato, ma percepisce la tensione al divino presente nell'uomo, e sente la liturgia come momento di comunione estetica in cui tale tensione si realizza, e che si esprime attraverso la parola.

3 Proprio l'esigenza di una liturgia rivela come per Mallarmé la religione non sia disgiunta dall'esigenza di un collettivo sociale. Le Divagations presentano una critica aspra alla società repubblicana, e di qualsiasi ordine politico, per difendere invece un ordine sociale che, dopo la crisi, ha bisogno di essere ricostituito attraverso una nuova forma religiosa. Tale forma non può essere cattolica, ma liturgica, fondata sulla 
consapevolezza del nulla e sulla tensione della messinscena simbolica. Come nella questione estetica, il Nulla assume valore contemporaneamente positivo e negativo, capace di rinnovare le tensioni intime dell'uomo. L'uomo si crea l'immagine di Dio ed è nel linguaggio che esprime l'elaborazione figurata del conflitto tra l'esistenza e la morte. L'A. conclude che Mallarmé ha ritrovato nella mitologia la chiave di una psicanalisi personale, e nel culto solare degli antichi, nella sua manifestazione di aurora e tramonto, ossia di nascita e morte, la rappresentazione di essere e non essere. 